\title{
Vertical migration patterns of the different larval instars of Chaoborus flavicans and the influence of dissolved oxygen concentrations
}

\author{
Manuel Weisser, Hilmar Hofmann, Jorge Encinas Fernández, and Frank Peeters
}

\begin{abstract}
Here we investigate the diel vertical migration (DVM) of the different larval stages of Chaoborus flavicans between spring and summer in two different lakes and three different years. Specific attention is given to the influence of the vertical distribution of dissolved oxygen (DO) on the DVM of the different larval instars. To our knowledge, this study is the first that combines continuous observations of DVM of $C$. flavicans with continuous measurements of DO distributions over several months, allowing the assessment of changes in DVM due to the development of hyperoxic conditions in the deep water of lakes. With ontogenetic development, $C$. flavicans larvae increase their sensitivity to changes in light intensity and their tolerance to low oxygen conditions. Our results suggest that the physiological changes of $C$. flavicans larvae are adaptations to seasonal changes in DO, improving migration abilities to enable utilization of hypoxic and anoxic waters to avoid predation. Interannual change in the abundance and vertical distribution of phytoplankton affecting DO concentrations was sufficient to alter DVM patterns of $C$. flavicans larvae between years.
\end{abstract}

Résumé : Nous examinons la migration verticale nycthémérale (MVN) des différents stades larvaires de Chaoborus flavicans du printemps à l'été dans deux lacs différents et durant trois années distinctes. Une attention spéciale est accordée à l'influence de la répartition verticale de l'oxygène dissous (OD) sur la MVN des différents stades larvaires. À notre connaissance, il s'agit de la première étude à combiner des observations continues de la MVN de C. flavicans à des mesures continues de l'OD sur plusieurs mois, rendant ainsi possible l'évaluation des modifications de la MVN résultant du développement de conditions hyperoxiques dans l'eau profonde de lacs. Au fil de leur développement ontogénique, les larves de $C$. flavicans accroissent leur sensibilité aux variations de l'intensité lumineuse et leur tolérance aux conditions pauvres en oxygène. Nos résultats donnent à penser que les changements physiologiques qui caractérisent les larves de $C$. flavicans constituent des adaptations aux variations saisonnières d'OD qui améliorent leur capacité de migration pour leur permettre d'utiliser des eaux hypoxiques et anoxiques afin d'éviter la prédation. Les variations interannuelles de l'abondance et de la répartition verticale du phytoplancton qui modulent les concentrations d'OD suffisent pour modifier les motifs de MVN de C. flavicans d'une année à l'autre. [Traduit par la Rédaction]

\section{Introduction}

The larvae of the phantom midge Chaoborus flavicans develop high biomasses in many eutrophic lakes (Malinen et al. 2001) and play an important role in lake ecosystems, as their predation on mesozooplankton affects the structure of the zooplankton community (Moore 1988; Lair 1990). The larvae perform diel vertical migration (DVM) to avoid predation by visually feeding planktivorous fish during daytime and to prey on other zooplankton in the upper part of the water column at night (Ohman et al. 1983; Luecke 1986; Voss and Mumm 1999; Malinen et al. 2001). The DVM of Chaoboridae is controlled in part by light intensity (Teraguchi and Northcote 1966; Swift and Forward 1980; Haney et al. 1990; Malinen et al. 2001; Stratton and Kesler 2007) and is affected by the concentration of dissolved oxygen (DO) (LaRow and Marzlof 1970; Stratton and Kesler 2007). Chaoborus flavicans has four larval instar stages, which are followed by a short pupal stage (Teraguchi and Northcote 1966). While larvae of instars III and IV have been reported to migrate vertically, younger larvae usually do not migrate to the same extent (Berg 1937; Teraguchi and Northcote 1966; Fedorenko and Swift 1972; Lewis 1975). Swift and Forward (1982) proposed that the smaller instar II larvae are not able to migrate, arguing that instar II larvae are adapted to the phototrophic zone of the water column because they lack a fully developed compound eye, which is required for receiving light cues in deep water. Both Teraguchi and Northcote (1966) and Gliwicz et al. (2000) have shown that the depth-selection behavior among the four larval instars differs. During daytime the residence depth of the different instars increases with the ontogenetic development. Voss and Mumm (1999) showed that larvae of instars I and II of C. flavicans were more abundant in the upper water column during the day but not at night, while the opposite pattern was observed for larvae of instars III and IV from May to October. According to Barth et al. (2014), instar II larvae of C. punctipennis show a reverse pattern of DVM during late June and switch to the normal pattern of DVM by late July.

Most of the studies that investigated the DVM of C. flavicans, the response of their DVM to changes in abiotic conditions, and the seasonal patterns of their DVM are based on traditional zooplankton sampling methods. Thus, the temporal resolution within individual days and the number of days investigated during the seasons has been limited. However, migration patterns of $C$. flavicans can also be identified based on acoustic measurements. Lorke et al. (2004) demonstrated that the backscatter strength (ABS) 
from $C$. flavicans measured with acoustic Doppler current profilers (ADCP) is four orders of magnitudes larger than from other zooplankton and that the large target strength may be explained by the presence of the air sacs in Chaoborus. Barth et al. (2014) were the first to utilize ADCP data to analyze vertical migration patterns of different larval instars of Chaoborus punctipennis.

Here we investigate the DVM patterns of different instars of C. flavicans continually from spring until summer in two different lakes and in three different years and relate the migration patterns to the seasonal development of the vertical distribution of DO. Migration patterns are identified based on ABS measured with ADCPs that were deployed in the two different lakes. These data are compared with results from traditional zooplankton samplings to distinguish the four larval instars of $C$. flavicans. The long-term ADCP records provide a continuity of information on the change in the migration patterns of the different larvae instars with a subdaily resolution over several months and thus is an excellent basis to investigate the relation between abiotic conditions and migration patterns. We specifically focus on the response of the migration patterns of the different larval instars of C. flavicans to changes in DO and therefore measured the vertical distribution of DO continually during the entire observation periods in both lakes. Based on these data, we investigate the hypotheses that (a) the timing of upward and downward migration differs among instars of $C$. flavicans because they have different visual capabilities and experience different light intensities at their residence depth during the day, $(b)$ the different instars of C. flavicans reside at different depths during daytime and the residence depth is affected by the vertical distribution of DO because their tolerance to low oxygen concentrations increases with ontogenetic stage, and $(c)$ the pattern of DVM changes seasonally in response to changes in the vertical distribution of DO and in particular with the development of a layer of anoxic deep water. Finally, we illustrate that the DVM patterns of the different larval stages of $C$. flavicans can differ substantially between years in response to changes in vertical distribution of DO. The latter became possible because a massive bloom of the cyanobacterium Planktothrix rubescens strongly affected the vertical distribution of DO in one of the years.

\section{Materials and methods}

\section{Study sites}

This research was conducted at two lakes, Lake Mindelsee and Lake Illmensee. Field data were collected at Lake Mindelsee between 4 April and 17 July 2015 and at Lake Illmensee between 4 May and 15 July 2013 and between 29 May and 15 July 2014. Lake Mindelsee is located in southern Germany $\left(47^{\circ} 45.178^{\prime} \mathrm{N}, 9^{\circ} 1.423^{\prime} \mathrm{E}\right)$ and has a surface area of $1.02 \mathrm{~km}^{2}$ and a maximum depth of $13.5 \mathrm{~m}$. Lake Mindelsee is a small mesotrophic, dimictic lake that mixes in autumn after the summer stratification and in early spring after the inverse stratification during ice coverage. During summer stratification, the lake typically develops an anoxic zone below 8 to $10 \mathrm{~m}$ water depth. The light extinction coefficient $(k)$, determined from vertical profiles of photosynthetically active radiation measured within the top $7 \mathrm{~m}$ of the water column, was $0.43 \mathrm{~m}^{-1}$ at the beginning (on 13 May) and towards the end (on 26 June) of our measuring period at Lake Mindelsee. Hence, the depth at which light intensity was $1 \%$ of the light intensity incident at the lake surface was at $\sim 10.7 \mathrm{~m}$.

Lake Illmensee is also located in southern Germany $\left(47^{\circ} 51.166^{\prime} \mathrm{N}\right.$ $9^{\circ} 22.449^{\prime} \mathrm{E}$ ) and has a surface area of $0.6 \mathrm{~km}^{2}$ and a maximum depth of $16.5 \mathrm{~m}$. It is a eutrophic, dimictic lake. During summer stratification, an anoxic zone develops typically below 9 to $11 \mathrm{~m}$ depth. The light extinction coefficient in Lake Illmensee differed slightly during the measuring periods and between years and ranged between 0.42 and $0.66 \mathrm{~m}^{-1}$ ( $k$ was $0.49 \mathrm{~m}^{-1}$ on 5 May 2013, $0.66 \mathrm{~m}^{-1}$ on 26 June $2013,0.46 \mathrm{~m}^{-1}$ on 8 May 2014 , and $0.42 \mathrm{~m}^{-1}$ on
26 June 2014). The depth at which light intensity was $1 \%$ of the light intensity incident at the lake surface was $9.4,7,10$, and $11 \mathrm{~m}$, respectively.

\section{Acoustic backscatter strength (ABS) and zooplankton detection}

A $614 \mathrm{kHz}$ four-beam ADCP (RDI Workhorse Sentinel, RDI Instruments, San Diego, USA) was deployed on the bottom of the respective lake (i.e., at $13.5 \mathrm{~m}$ water depth in Lake Mindelsee and at $16.5 \mathrm{~m}$ water depth in Lake Illmensee) and measured in upward direction. The ping rate of the ADCP was $\sim 0.6 \mathrm{~Hz}$, and the signals were averaged to provide a sampling interval of $30 \mathrm{~s}$. The vertical bin size was $0.5 \mathrm{~m}$. Chaoborus larvae can be detected by lowfrequency acoustic devices, because air sacs used by the larvae for buoyancy adjustment cause strong ABS (Voss and Mumm 1999). The ABS of a $614 \mathrm{kHz} A D C P$ is substantially enhanced by the presence of $C$. flavicans and is less sensitive to the abundance of crustacean zooplankton than to the abundance of $C$. flavicans (Lorke et al. 2004). According to Bathes et al. (2014), the ABS measured with a $614 \mathrm{kHz}$ ADCP deployed in Lake Openogo was dominated by the backscatter from C. punctipennis and indicates DVM of this species. Here we utilize the ABS measured with a $614 \mathrm{kHz}$ ADCP to investigate the DVM of the larvae stages of $C$. flavicans. The ABS intensity received from each depth cell of the four beams was corrected for the effects of beam spreading and absorption in the water column as described by Lorke et al. (2004). The resulting ABS of the four beams were averaged. Because of the mounting of the instrument and the blanking distance, ABS are available only from $\sim 1.8 \mathrm{~m}$ above the lake bottom. The ABS in the uppermost $2 \mathrm{~m}$ of the water column are considered unreliable because of gas bubbles and turbulence affecting the acoustic signals. Hence, vertical profiles of ABS data cover the depth range from $1.8 \mathrm{~m}$ above the lake bottom to $2 \mathrm{~m}$ below the water surface.

\section{Dissolved oxygen (DO) concentration}

DO concentrations were recorded by miniDOT Loggers (Optodes, Precision Measurement Engineering, Inc., PME, Vista, USA). These loggers were mounted in a vertical chain at the ADCP mooring site. In Lake Mindelsee, the different $\mathrm{O}_{2}$ optodes were mounted at 1.2, 2.2, 3.2, 4.2, 6.2, 7.2, 9.2, 10.2, 12.2, and $13.2 \mathrm{~m}$ water depth. In Lake Illmensee, the $\mathrm{O}_{2}$ optodes were mounted at $0.9,2.4,4.4,6.4,8.4$, 11.4 , and $13.9 \mathrm{~m}$ water depth in 2013 and at 1.2, 3.2, 5.2, 7.2, 9.2, 11.2, 13.2, and $15.2 \mathrm{~m}$ water depth in 2014. The measuring interval was $60 \mathrm{~s}$.

\section{Phytoplankton}

Vertical profiles of phytoplankton concentrations were determined with a multispectral FluoroProbe (Moldaenke FluoroProbe, MFP; BBE MOLDAENKE, Schwentinental, Germany). The MFP measures fluorescence at several wavelengths and uses relative fluorescence intensities to estimate the concentration of several algal groups and the total chlorophyll $a$ equivalent concentration (total Chl $a$ eq). In addition, the MFP is equipped with a temperature sensor that provides vertical profiles of temperature.

\section{Zooplankton}

Zooplankton was collected with a closing net (Apstein's type; Hydrobios GmbH, Altenholz, Germany) with a mesh size of $100 \mu \mathrm{m}$ and an opening diameter of $16.5 \mathrm{~cm}$. The filtrated water volume during a net haul is $21.4 \mathrm{~L} \cdot \mathrm{m}^{-1}$.

In Lake Mindelsee, zooplankton samples were collected on 18 and 19 June 2015. Samples were taken at dusk (2026-2107 h), at night (0002-0034 h), at dawn $(0332-0407 \mathrm{~h})$, and during the day (1058-1137 h). Each profile comprised 10 net hauls with a vertical range of $1 \mathrm{~m}$, resolving the vertical distribution from 2 to $12 \mathrm{~m}$ water depth in $1 \mathrm{~m}$ steps. The profiles taken at night, dawn, and day started with the lowermost sample and ended with the uppermost sample, while the profile taken at dusk was collected in 
Fig. 1. (a) Acoustic backscatter strength (ABS) and (b) the vertical distribution of $C$. flavicans larvae instars measured in zooplankton samples for the time period 18-19 June 2015 in Lake Mindelsee. Black lines indicate the timing of zooplankton sampling (dusk, night, dawn, and day profiles). Profiles of zooplankton samples were collected in $1 \mathrm{~m}$ steps using $1 \mathrm{~m}$ net hauls.
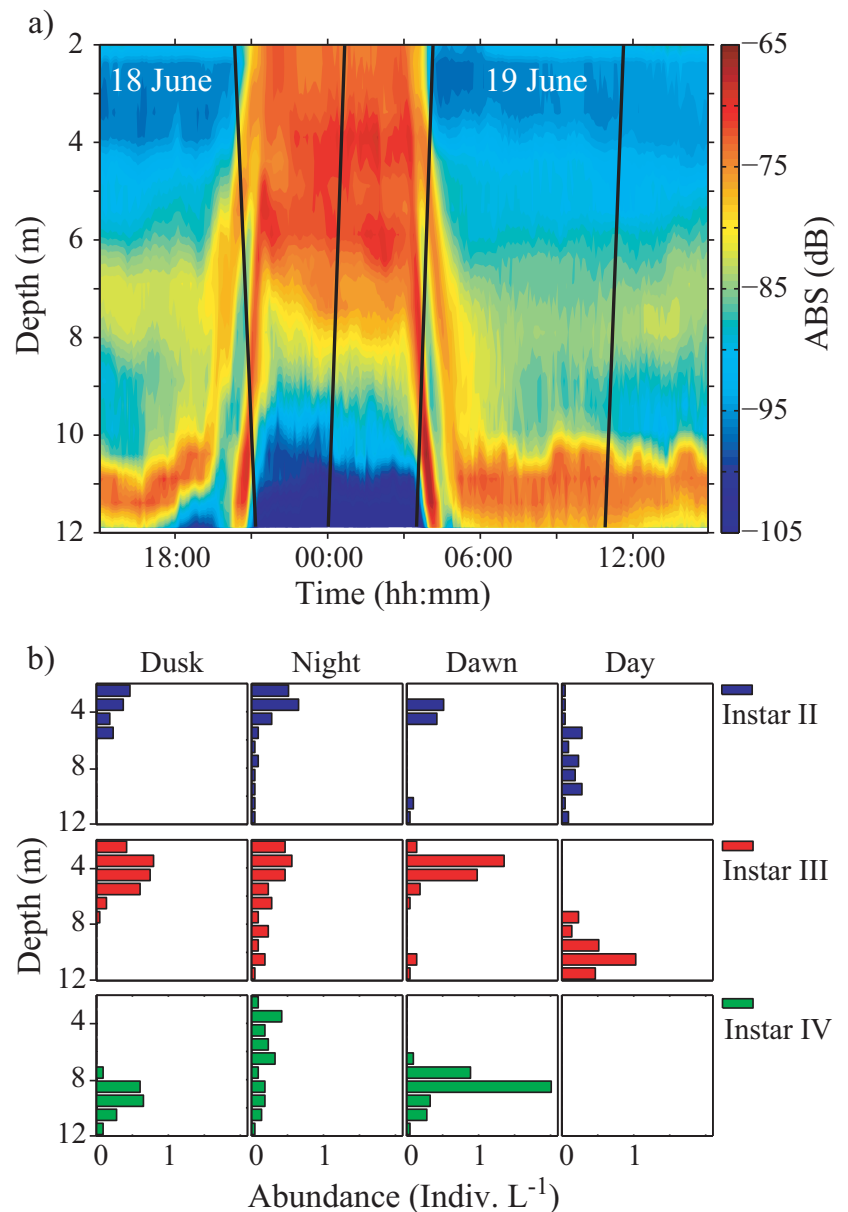

reverse order. Note that the timing of the zooplankton sampling from the different depths is indicated by the black lines in Figs. 1a, $2 a$, and $3 a$. The sampling strategy was chosen to support the identification of the different migrating groups by accounting for the direction of migration and for the time required to sample the zooplankton profile.

In Lake Illmensee, profiles of zooplankton samples were collected on 27 and 28 June 2014. The first sampling was conducted at dusk (2050-2120 h), the second close to midnight (2300-2335 h), the third at dawn $(0325-0400 \mathrm{~h})$, and the fourth during daylight (0720-0800 h). In 2014, all the profiles were sampled using $1 \mathrm{~m}$ net hauls resolving the vertical distribution from 2 to $13 \mathrm{~m}$ in $1 \mathrm{~m}$ steps starting with the uppermost sample. In 2013, zooplankton sampling took place on 5 May during daylight (1200-1240 h) and at night (2300-2330), as well as on 26 June during daylight (1200$1245 \mathrm{~h}$ ). On 5 May, zooplankton was sampled using net hauls of $4 \mathrm{~m}$ collecting samples from 0 to 4,4 to 8 , and 8 to $12 \mathrm{~m}$, whereas on 26 June, $3 \mathrm{~m}$ net hauls were used collecting four samples from 0 to 3,3 to 6,6 to 9 , and 9 to $12 \mathrm{~m}$.

Zooplankton samples were washed into $100 \mathrm{~mL}$ bottles and preserved in $4 \%$ sucrose-formaldehyde solution approximately $10 \mathrm{~min}$ after sampling. The abundance of the $C$. flavicans instars in each sample was counted and later compared with the ABS measured by the ADCP at the corresponding depth range. Chaoborus larvae
Fig. 2. (a) ABS and (b) the vertical distribution of $C$. flavicans larvae instars measured in zooplankton samples for the time period 27-28 June 2014 in Lake Illmensee. Black lines indicate the timing of zooplankton sampling (dusk, night, dawn, and day profiles). Profiles of zooplankton samples were collected in $1 \mathrm{~m}$ steps using $1 \mathrm{~m}$ net hauls.
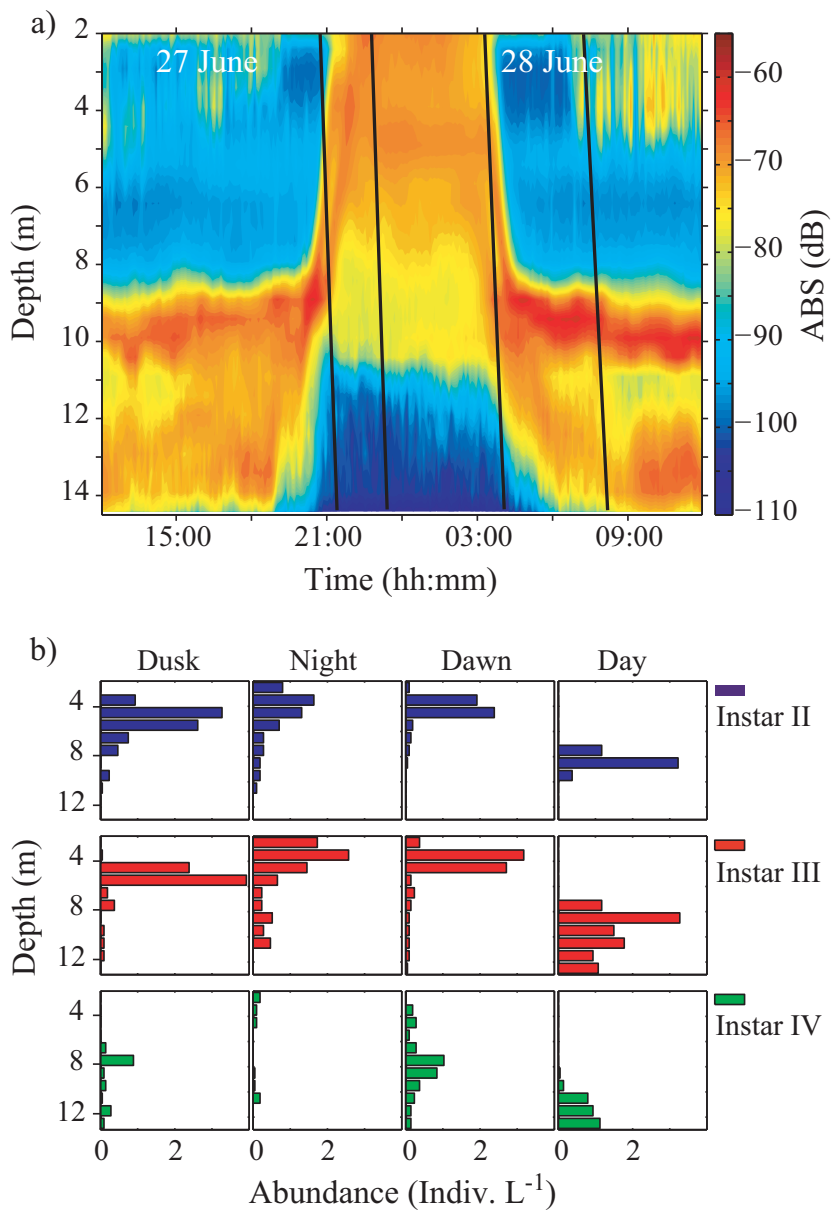

were removed from each sample by filtration through an $80 \mu \mathrm{m}$ mesh filter. The organisms were placed into a circular counting dish and were counted and measured under a binocular microscope. The body length of the larvae and the existence of the second compound eye were used to distinguish between the different larval stages (Parma 1971; Chimney et al. 2007). Body length distributions overlapped especially between larvae of instars II and III, requiring the discrimination between the two instars based on the existence of the second compound eye. The total concentration of individuals was determined by counting the number of individuals in the sample and dividing by the volume of the water filtered by the plankton net. The only Chaoborus species found in Lake Mindelsee and Lake Illmensee was C. flavicans as it was already described by Smukalla and Meyer (1988) and more recently by Martin-Creuzburg et al. (2017). An additional taxonomic identification was done by Tony Irwin (Senior Curator of Natural History at Norfolk Museums).

In the samples collected at 3-6, 6-9, and 9-12 $\mathrm{m}$ depth in Lake Illmensee on 26 June 2013, we counted additional zooplankton, distinguishing between small $(<1 \mathrm{~mm})$ and large $(>1 \mathrm{~mm})$ Daphnia, small $(<1 \mathrm{~mm})$ and large $(>1 \mathrm{~mm})$ Copepoda, and larger invertebrates (e.g., Leptodora, Bytotrephes). 
Fig. 3. (a) ABS and (b) the vertical distribution of $C$. flavicans larvae instars measured in zooplankton samples for the time period 25-27 June 2013 in Lake Illmensee. (c) ABS measured for 10-11 July 2013 in Lake Illmensee. The black line in panel $(a)$ indicates the timing of zooplankton sampling (day profile). The profile of zooplankton samples was collected in $3 \mathrm{~m}$ steps using $3 \mathrm{~m}$ net hauls.
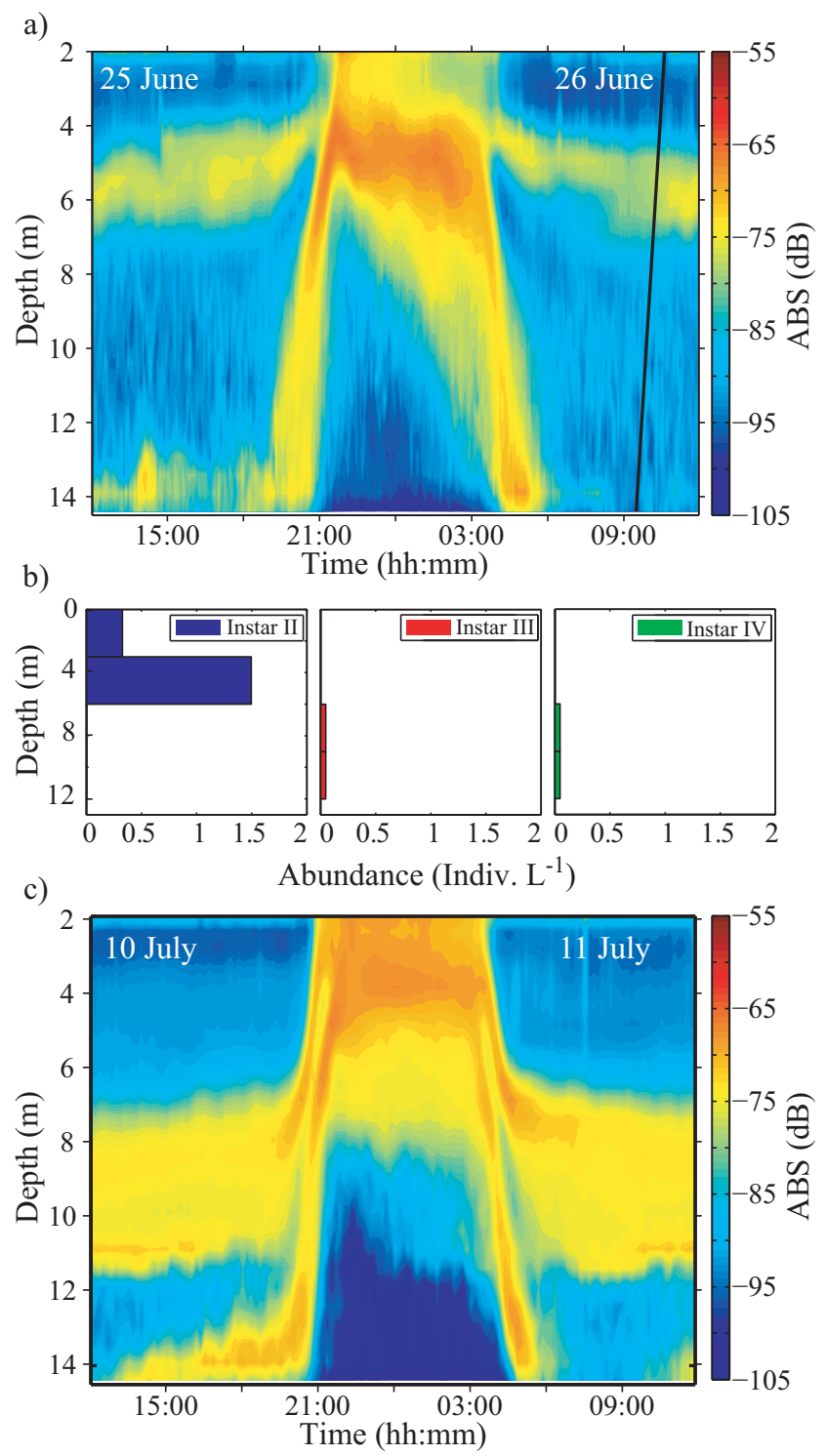

\section{Results}

\section{Zooplankton abundance}

The time series of the vertical distribution of the ABS from all measuring campaigns are characterized by distinct layers of increased ABS that show pronounced daily cycles in their vertical position (Figs. 1a, 2a, 3a, 3c, 4, 5, 6). These layers reflect the predominant position of different instars of $C$. flavicans larvae, and the vertical displacements of the layers thus indicate the vertical migration patterns of the different instars.

The association of the different layers of increased ABS with different larval instars is illustrated for a $24 \mathrm{~h}$ time period from 18 to 19 June 2015 in Lake Mindelsee (Fig. 1a). Three layers of increased ABS can be distinguished, which suggest highly synchronized migration cycles of three different instars of $C$. flavicans. One of the backscatter layers indicates a migration pattern that was characterized by vertical movement starting between 1800 and $1900 \mathrm{~h}$ from $11 \mathrm{~m}$ depth towards the lake surface, reaching 4-5 $\mathrm{m}$ at about $2000 \mathrm{~h}$. Downward migration set in on 19 June from $\sim 4 \mathrm{~m}$ at $0400 \mathrm{~h}$ returning to the deep water at $\sim 11 \mathrm{~m}$ water depth around $0600 \mathrm{~h}$. The results from the zooplankton sampling indicate that the temporal changes in the vertical distribution of instar III larvae (Fig. 1b) (i.e., the depth of the maximum abundance of instar III larvae) closely corresponded to the depth of the backscatter layer described above. During the day, the maximum abundance of instar III larvae was in the depth range of 10-11 m, whereas at $\sim 2000 \mathrm{~h}$, at midnight, and at $\sim 0400 \mathrm{~h}$, maximum abundances of instar III larvae occurred between 3 and $5 \mathrm{~m}$ water depth (Fig. 1b).

The second layer of enhanced ABS suggests migration of organisms that were not present in the measuring range of the ADCP during daytime but occurred at the maximum measuring depth of $12 \mathrm{~m}$ shortly before $2100 \mathrm{~h}$. These organisms passed $10 \mathrm{~m}$ water depth at $\sim 2100 \mathrm{~h}$ (i.e., more than $1 \mathrm{~h}$ later than the instar III larvae) and reached $5 \mathrm{~m}$ at $\sim 2200 \mathrm{~h}$. They started their downward migration earlier than instar III larvae. On the way back towards the deep water, they passed $9 \mathrm{~m}$ water depth at $\sim 0400 \mathrm{~h}, 1 \mathrm{~h}$ earlier than instar III larvae, and migrated then to depths below the measuring range of the ADCP. This migration pattern indicated by the vertical displacements of the second layer of enhanced ABS corresponds very well to the temporal change in the vertical distribution of the instar IV larvae (Fig. 1b). During the day, instar IV larvae were absent in the water column and most likely stayed in the sediments. At dawn and dusk, they occurred in considerable number at 9-10 and 8-9 m water depth, respectively (Fig. 1b). The vertical distribution patterns agree very well with the depth of the second layer of enhanced ABS (Fig. 1). At night, the larvae were distributed over the entire water column.

On 18 and 19 June, a third layer of enhanced ABS can be recognized at around $7 \mathrm{~m}$ during daytime (Fig. 1a). The zooplankton data suggest that this backscatter signal originates mainly from instar II larvae and to a lesser extent from instar III larvae (Fig. 1b). Instar II larvae are distributed between 5 and $10 \mathrm{~m}$ water depth during daytime and between 2 and $5 \mathrm{~m}$ water depth at night. The smaller instar II larvae apparently performed a regular DVM pattern but with a comparatively small amplitude.

The observations on the DVM patterns of the different instars of C. flavicans in Lake Mindelsee are compared with backscatter data from Lake Illmensee (Fig. 2a). During 27 and 28 June 2014, only two different layers of enhanced ABS are clearly distinguishable in Lake Illmensee, both suggesting regular DVM of two different instars of $C$. flavicans (Fig. $2 a$ ). The first group of larvae started its upward migration from $\sim 10 \mathrm{~m}$ water depth at $\sim 2000 \mathrm{~h}$ and returned at $\sim 0330 \mathrm{~h}$. During daytime these larvae stayed at around 9-10 $\mathrm{m}$ and were identified to be larvae of instars II and III, both with nearly the same abundance (Fig. 2b). The second group of larvae (instar IV; see Fig. $2 b$ ) began its vertical migration earlier than larvae of instars II and III, but started its migration from deeper water (12-14 m). On the way back, instar IV larvae started their downward migration earlier than larvae of instars II and III, but reached their depth of residence during daytime after them. In June 2014 during daytime, instar IV larvae apparently stayed in the depth range between 12 and $14 \mathrm{~m}$ and did not migrate into the sediment.

In 2013 zooplankton samples collected on 5 May in Lake Illmensee indicate that during daylight (1200-1240 h) no C. flavicans larvae and at night only instar IV larvae were present, mostly in the upper $4 \mathrm{~m}$. Consistently, the ABS in May 2013 was low during the day and only increased during nighttime darkness (Fig. 5). On 26 June 2013 during daylight (1200-1245 h), no larvae of instar III and instar IV were abserved, but instar II larvae were observed. The instar II larvae were most abundant between 3 and $6 \mathrm{~m}$ water depth (Fig. 3b), and the ABS data are consistent with this observation (Fig. 3a). According to Lorke et al. (2004) Chaoborus dominates 
Fig. 4. Long-term ABS measured between 4 May and 14 July in 2015 in Lake Mindelsee. Always 2 consecutive days are depicted with varying distance between such 2-day periods. The white line indicates the $3.5 \mathrm{mg} \cdot \mathrm{L}^{-1} \mathrm{DO}$ isoline, and the black line indicates the $0.5 \mathrm{mg} \cdot \mathrm{L}^{-1} \mathrm{DO}$ isoline. Grey bars in the plot indicate missing data.

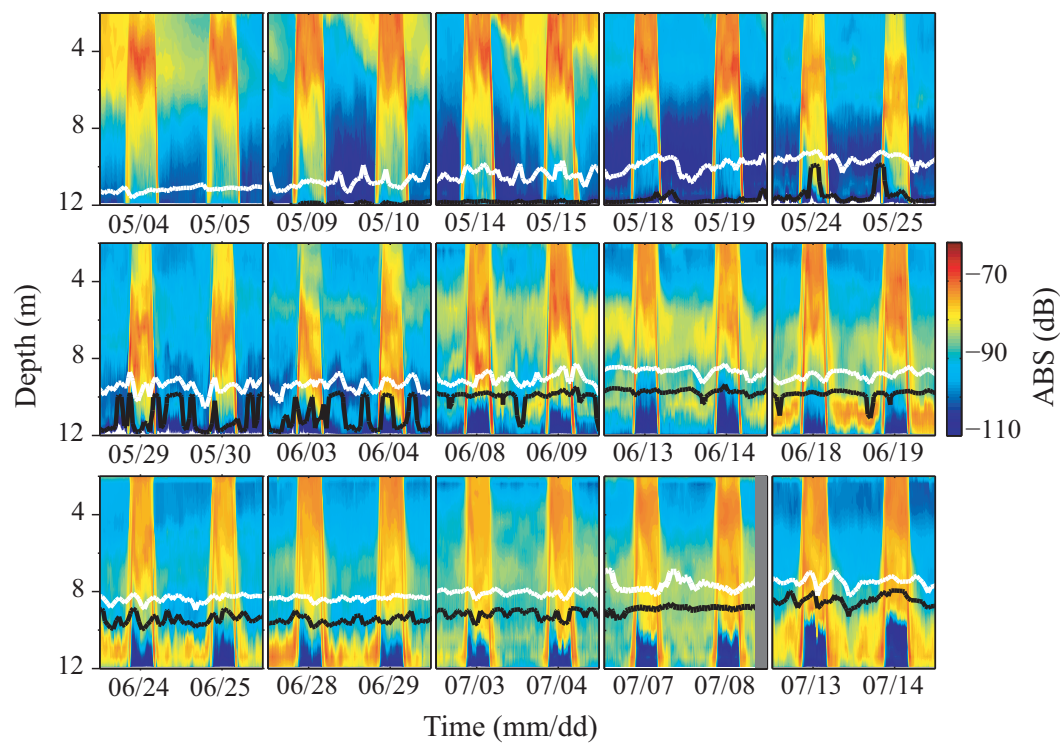

Fig. 5. Long-term ABS measured between 4 May and 15 July in 2013 in Lake Illmensee with $3.5 \mathrm{mg} \cdot \mathrm{L}^{-1} \mathrm{DO}$ isoline (white line) and $0.5 \mathrm{mg} \cdot \mathrm{L}^{-1} \mathrm{DO}$ isoline (black line). Gaps occur in the isolines when the respective value was not present in the water column.

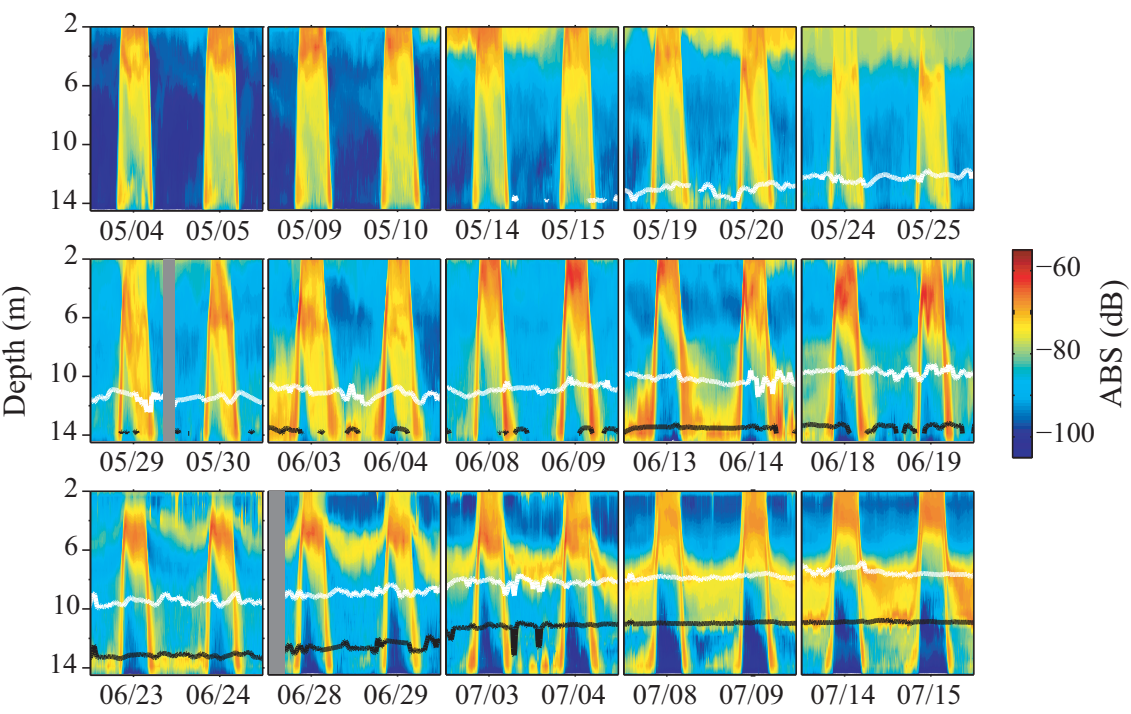

Time $(\mathrm{mm} / \mathrm{dd})$

the ABS signal over other zooplankton by more than four orders of magnitude. The abundances of zooplankton groups other than Chaoborus did not vary much between 3 and $12 \mathrm{~m}$ depth (Table 1). Macrozooplankton (e.g., Leptodora, Bytotrephes) were essentially absent. The abundances of small and large Daphnia and small and large Copepoda were similar to each other. Large Daphnia $(>1 \mathrm{~mm})$, which have a larger acoustic target strength than small Daphnia and Copepoda (Huber et al. 2011), were more abundant between 9 and $12 \mathrm{~m}$ than between 3 and $9 \mathrm{~m}$ depth. The layer of increased $\mathrm{ABS}$ at $\sim 6 \mathrm{~m}$ in Fig. $3 a$ therefore indicates instar II Chaoborus larvae rather than other zooplankton.

During the night from 25 to 26 June, the ABS data indicate an additional group of Chaoborus instar larvae migrating upwards from the sediment towards the upper part of the water column. This ABS signal is most likely due to instar IV larvae, which were performing DVM since the beginning of the sampling period. Note that in July 2013, the vertical migration pattern in Lake Illmensee is similar to that in Lake Mindelsee in 2015, as the ABS data suggest three distinct groups with different migration patterns and different residence depths during daytime (Fig. 3c). The additional third group at about $11 \mathrm{~m}$ may be instar III larvae that have developed from instar II larvae present in June.

In all the zooplankton samples mentioned above, no instar I larvae and no pupae were observed. Instar I larvae develop very fast into the second instar (Von Ende 1982; Lagergren et al. 2008), and it is therefore unlikely to detect this larval stage if net sampling of zooplankton is only sporadic. The pupal stage only lasts 2-4 days (Diomande et al. 2010). The pupae do not feed and have to live on stored material (Parma 1971; Jäger and Walz 2003). Possibly, pupae minimize energetic costs by staying in the sediments as 
Fig. 6. Long-term ABS measured between 29 May and 15 July in 2014 in Lake Illmensee with $3.5 \mathrm{mg} \cdot \mathrm{L}^{-1} \mathrm{DO}$ isoline (white line) and $0.5 \mathrm{mg} \cdot \mathrm{L}^{-1} \mathrm{DO}$ isoline (black line).

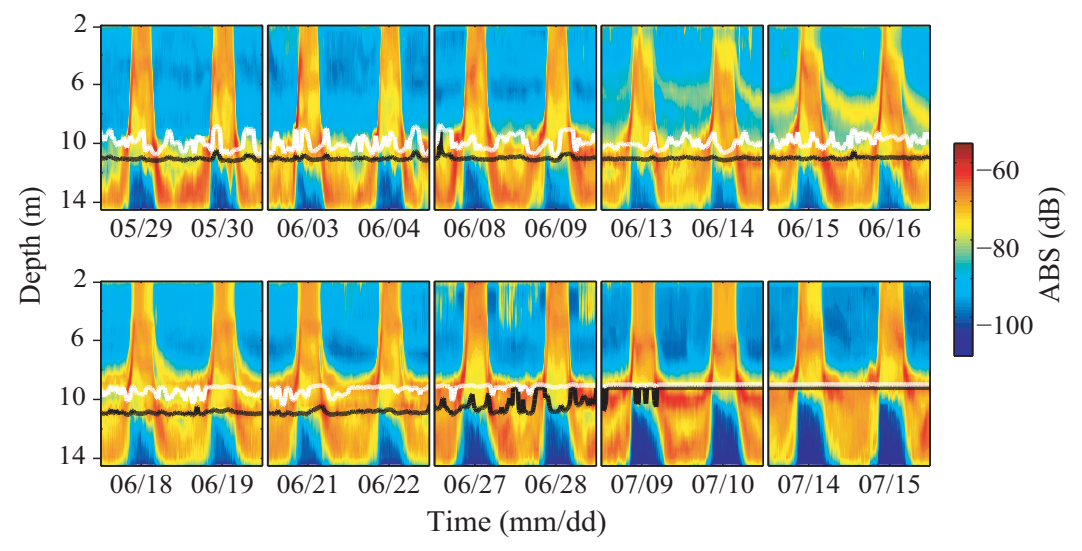

Table 1. Abundances of zooplankton in Lake Illmensee on 26 June 2013.

\begin{tabular}{llllll}
\hline Depth $(\mathrm{m})$ & $\begin{array}{l}\text { Daphnia } \\
\text { big }\left(\mathrm{L}^{-1}\right)\end{array}$ & $\begin{array}{l}\text { Daphnia } \\
\text { small }\left(\mathrm{L}^{-1}\right)^{*}\end{array}$ & $\begin{array}{l}\text { Copepoda } \\
\text { big }\left(\mathrm{L}^{-1}\right)\end{array}$ & $\begin{array}{l}\text { Copepoda } \\
\text { small }\left(\mathrm{L}^{-1}\right)\end{array}$ & $\begin{array}{l}\text { Macrozooplankton } \\
\left(\mathrm{L}^{-1}\right)\end{array}$ \\
\hline $3-6$ & 3.05 & 4.98 & 1.65 & 6.10 & 0.06 \\
$6-9$ & 3.33 & 6.14 & 1.25 & 5.20 & 0.03 \\
$9-12$ & 3.96 & 2.00 & 0.37 & 4.33 & 0.00 \\
\hline
\end{tabular}

*Note that the group of small Daphnia contain also Bosmina sp.

long as possible and leave the sediments just prior to hatching. Such a behavior may explain their absence in our net hauls. Because of the fast development of instar I into instar II and the short duration of pupal stage, the observed layers of increased ABS mainly indicate the presence of larvae of instars II, III, and IV of $C$. flavicans.

\section{Long-term record of ABS}

Our long-term data on ABS, covering the season from spring to mid-July in each of the two lakes and in 2 consecutive years in Lake Illmensee, indicate seasonal changes in the DVM patterns of the different instars.

Between May 2015 and the middle of July 2015, the ABS in Lake Mindelsee is characterized by distinct layers showing highly synchronized daily cycles of vertical displacements that change seasonally (Fig. 4). At the beginning of May, the ABS was low during daylight and high between dusk and dawn during each day. This pattern was due to $C$. flavicans larvae that migrated to the surface waters at dusk and returned to the sediment at dawn. At the end of May and the beginning of June, a second backscatter layer in the upper 4-6 $\mathrm{m}$ occurred and is visible during day- and nighttime. The second backscatter layer became more evident with time, reaching maximum ABS in the middle of June. Afterwards, it decreased in intensity until it completely vanished by the middle of July. On 13 June, when this layer had reached its highest $\mathrm{ABS}$, the layer had also moved a little downwards to a water depth of 6-8 $\mathrm{m}$ during daytime and indicated a normal DVM pattern.

At the beginning of June, a third layer is visible in the ABS data at $\sim 10-11 \mathrm{~m}$ water depth (Fig. 4). The ABS of this layer continuously increased with time and reached a maximum on 18 June. During the entire time period, this layer shows a pattern typical for larvae performing a DVM. On 18 June, when this layer had reached its highest intensity, the ABS of the layer above had strongly decreased. From 18 June onwards, the ABS of the third backscatter layer decreased with time and moved downwards to 11-12 m.

The fading of a backscatter layer and the simultaneous increase in ABS of another backscatter layer at larger depth suggests the transition from one instar stage to the next (i.e., the abundance of larger instar larvae increases at the expense of the abundance of the smaller instar larvae). The change in abundance is reflected by an increase and a decrease in the ABS, respectively. The zooplankton data from 18 June suggest that instar II larvae had just developed into instar III larvae. From 18 June onwards, instar III larvae develop into instar IV larvae, which explains the decreasing ABS of the layer at 11-12 $\mathrm{m}$ water depth.

The maximum depth of the DVM (i.e., the residence depth during daylight) is connected to the vertical distribution of DO. DO typically decreased with increasing depth (Fig. 7), except in Lake Illmensee in 2014 when an intermediate oxygen maximum occurred at $\sim 8 \mathrm{~m}$ depth (Fig. $7 \mathrm{~b}$ ). However, as in the other lakes and also in Lake Illmensee in 2014, DO decreased towards maximum water depth. In the deepest parts of all lakes, anoxic conditions developed over the season in all years. The depth of the $3.5 \mathrm{mg} \cdot \mathrm{L}^{-1} \mathrm{DO}$ isoline (Figs. 4-6, white line) indicates the maximum depth with tolerable DO concentrations for predating fish (Moore 1942), and the depth of the $0.5 \mathrm{mg} \cdot \mathrm{L}^{-1} \mathrm{DO}$ isoline (Figs. 4-6, black line) indicates the boundary to the anoxic deep water. Larvae of instars I and II apparently never moved to regions with DO concentrations below $3.5 \mathrm{mg} \cdot \mathrm{L}^{-1}$, whereas instar III larvae migrated to regions with DO below $3.5 \mathrm{mg} \cdot \mathrm{L}^{-1}$ but not to anoxic regions. Instar IV larvae typically resided in anoxic regions during daytime but not at night (Fig. 4).

In Lake Illmensee, the DVM patterns differed between years. At the beginning of the sampling period in 2013, the DVM patterns in Lake Illmensee (Fig. 5) resembled the DVM patterns in Lake Mindelsee early in the season in 2015 (Fig. 4). Only instar IV larvae were present at night in May 2013, and they were completely absent in the water column during daytime. Until the end of May, the deep water was oxygenated, and the ABS data suggest a similar migration pattern during the entire time period. The migration pattern changed with the occurrence of larvae of instars I and II in the upper regions of the water column around middle of June and the development of instar III larvae around the beginning of July.

In 2014, a backscatter layer with high ABS occurred at 12-14 m water depth at the beginning of the sampling period (Fig. 6). This layer, which resulted from instar IV larvae, indicates a regular DVM. But the instar IV larvae apparently did not fully migrate into the sediment of Lake Illmensee during the entire time period of 
Fig. 7. Vertical profiles of temperature (black), DO (blue), and total Chl $a$ eq (magenta). The data depicted were measured on (a) 26 June 2013 , $0900 \mathrm{~h}$ in Lake Illmensee, (b) 26 June 2014, $0930 \mathrm{~h}$ in Lake Illmensee, and (c) 26 June 2015, $0915 \mathrm{~h}$ in Lake Mindelsee. The depth at which light intensity is $1 \%$ of the intensity of the incident light at the lake surface is depicted in each panel as the horizontal dashed line.
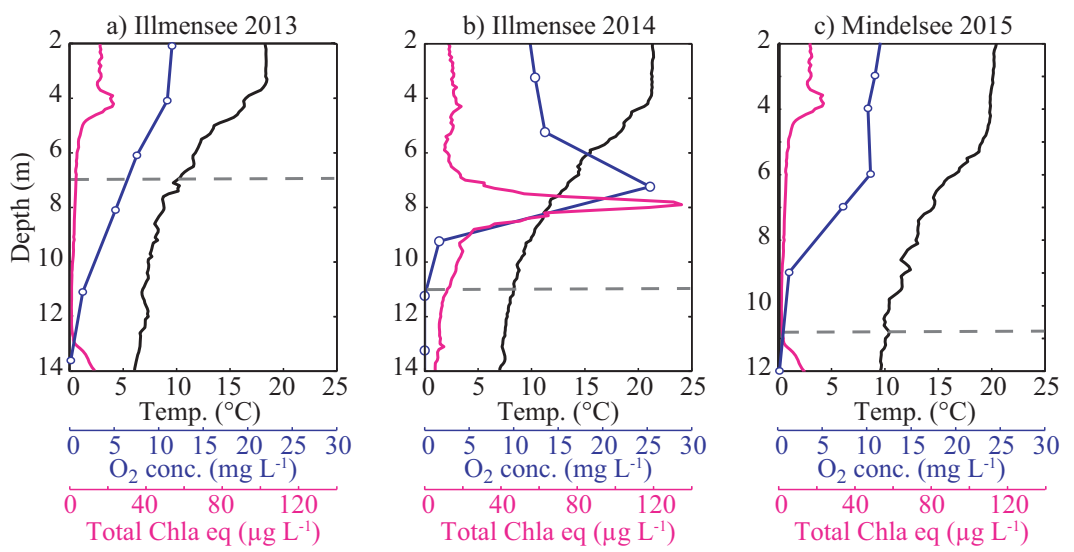

observation in 2014. This is also confirmed by Figs. $2 a$ and $2 b$, but differs from the migration patterns in Lake Mindelsee in 2015 (Figs. 1, 4) and in Lake Illmensee 2013 (Fig. 5).

These differences in the migration patterns may be explained by the differences in the vertical distribution of DO between the two lakes and between the 2 years in Lake Illmensee. In springearly summer 2015, Lake Mindelsee was oxic down to the sediments, and the conditions in Lake Illmensee in 2013 were similar to those in Lake Mindelsee. In contrast, in 2014 the $0.5 \mathrm{mg} \cdot \mathrm{L}^{-1} \mathrm{DO}$ isoline reached up to $11 \mathrm{~m}$ water depth in Lake Illmensee, and the lowest $5 \mathrm{~m}$ of the lake water column were completely anoxic, even at the beginning of the sampling period.

In 2014 in Lake Illmensee, larvae of instars I and II developed in the middle of June at about the same time as in 2013 but slightly later than larvae in Lake Mindelsee in 2015. In the middle of June a third layer of enhanced ABS occurred, which had a maximum ABS at 10-11 m water depth and was caused by instar III larvae.

The data from the zooplankton sampling conducted on 27 June 2014 confirm that the backscatter layers resulting from larvae of instars II and III overlap at $\sim 9 \mathrm{~m}$ (Fig. 2). Instar II larvae reached their maximum depth, apparently limited by $3.5 \mathrm{mg} \cdot \mathrm{L}^{-1} \mathrm{DO}$, which at this time was close to the upper residence depth of instar III larvae just above the boundary of the anoxic zone.

The vertical distribution of the DO concentrations appears not only to influence the maximum residence depth of the larvae during daytime but also their maximum residence depth during nighttime. During nighttime, essentially no larvae stayed at water depths below the $3.5 \mathrm{mg} \cdot \mathrm{L}^{-1} \mathrm{DO}$ isoline. When DO exceeded $3.5 \mathrm{mg} \cdot \mathrm{L}^{-1}$ everywhere in the water column (Figs. 4 and 5; beginning of May), larvae were distributed over the entire water column.

The differences in the vertical distribution of DO in 2013 and in 2014 in Lake Illmensee were associated with substantial differences in the abundance of the cyanobacterium P. rubescens. Figure 7 shows the total Chl $a$ eq for the different years. In 2014, a deep chlorophyll maximum (DCM) occurs at $\sim 8 \mathrm{~m}$ depth with up to $137 \mu \mathrm{g} \cdot \mathrm{L}^{-1} \mathrm{Chl} a$ eq. The DCM was caused by a dense layer of the cyanobacterium P. rubescens at this depth. The DCM was associated with the highest oxygen concentrations within the water column, and oxygen saturation exceeded $200 \%$, suggesting strong local oxygen production. Photosynthesis by $P$. rubescens can result in substantial production of oxygen (Cuypers et al. 2011; Garneau et al. 2013) and thus may explain the local oxygen maximum. Below the DCM in Lake Illmensee in 2014, DO decreased rapidly at $\sim 11 \mathrm{~m}$ depth because the water was anoxic. In contrast with the conditions in 2014 in Lake Illmensee, no DCM and also no oxygen maximum was observed at intermediate depths in 2013 in Lake Illmensee and in 2015 in Lake Mindelsee (Fig. 7).

\section{Discussion}

Long-term ABS records from two different lakes and 3 different years allowed a detailed characterization of the migration behavior of the different instars of $C$. flavicans larvae during their ontogenetic development and related the migration patterns of the different instars to the abiotic conditions, here specifically the vertical distribution of DO. During daytime, Chaoborus larvae migrate to larger water depth to reduce predation risk by visually hunting fish (Ohman et al. 1983; Luecke 1986; Voss and Mumm 1999; Malinen et al. 2001). Thereby, Chaoborus larvae utilize the decrease in light intensity with increasing water depth. Our data indicate that with their ontogenetic development, $C$. flavicans larvae increase their depth of residence during daylight and the amplitude of their DVM.

The changes in vertical distribution and migration amplitude may be explained by the argument that larger instars are better visible to predating fish and are more preferred food than smaller instar larvae (Voss and Mumm 1999). Additionally, physiological differences between different instars may constrain the migration amplitude and affect the timing of vertical migration of larval instars. Specifically, the eyes of the larvae develop during instars I and II, and only instar III have fully developed eyes (Swift and Forward 1982). Thus, instar II larvae may be less sensitive to light than larvae of instars III and IV, which could explain why instar II larvae show much smaller amplitudes of DVM than larvae of instars III and IV (Figs. 1, 2, and 3). However, in spite of the limited visual capabilities of instar II larvae, they performed DVM in both lakes and in all years (Fig. 4, June; Fig. 5, June-July; Fig. 6, June). The timing of migration of larvae of instars III and IV suggests that instar IV larvae are more responsive to low light intensities than instar III larvae, as they start migrating upwards later and downwards earlier than instar III larvae.

The migrational patterns of $C$. flavicans change seasonally, causing complex diel patterns in the ABS that change from early spring to mid-July. The long-term changes in DVM and in the vertical distribution of $C$. flavicans instars can be linked to the ontogenetic development of $C$. flavicans. The combination of the results from the backscatter data with the results from the analysis of the zooplankton samples suggests the following interpretation of the seasonal change in migrational patterns in Lake Mindelsee and Lake Illmensee. Very early in the season, only overwintering instar IV larvae are present in the lakes, followed by the development of instars I and II, which perform regular DVM from early on but with a comparatively small amplitude. Their depth of residence during the day is limited by the $3.5 \mathrm{mg} \cdot \mathrm{L}^{-1} \mathrm{DO}$ isoline. After a few weeks, instar II larvae develop into instar III larvae, 
which then migrate into zones with $\mathrm{DO}<3.5 \mathrm{mg} \cdot \mathrm{L}^{-1}$ but not into anoxic waters. Only instar IV larvae are able to migrate into anoxic zones, and when the anoxic water layer is thin or absent, instar IV larvae migrate into the sediments. Whereas younger instar larvae of $C$. punctipennis were reported to perform inverse DVM during spring-summer (Barth et al. 2014), this phenomenon was not observed for $C$. flavicans in our data from Lake Mindelsee and Lake Illmensee. Our data, covering the time period from spring to early summer, suggest that even the smaller instar larvae of $C$. flavicans perform a regular DVM (e.g., Figs. 1-3).

DVM is a behavior that utilizes the decrease of light intensity with depth and the diel change in light intensity. The latter acts as a trigger setting the timing of DVM, whereas the former affects the migration amplitude, providing an escape niche from fish predation during daytime in deep waters. However, in addition to the gradient in light intensity, our results suggest that $C$. flavicans larvae also utilize the decline in the DO concentration with depth to avoid predation by fish. The comparison of the migration patterns between years in Lake Illmensee indicates that the DO concentration affects the maximum migration depth of the different instars (i.e., the residence depth during daytime). With respect to the physiological constraints of migration, life history development of $C$. flavicans is apparently optimized to avoid fish predation, utilizing not only the decline of light intensity with depth but also the seasonal change in DO concentrations in lakes. Younger instars of $C$. flavicnas have a significantly higher oxygen consumption per mass than older instars (Jäger and Walz 2003). Thus, physiological constrains may explain why smaller larvae instars do not migrate into regions with $\mathrm{DO}$ concentrations below $3.5 \mathrm{mg} \cdot \mathrm{L}^{-1}$ and stay in the upper water column. As fish hunt visually, escaping predation by utilizing safe niches becomes more important for larger larvae. After the transition from instar II to instar III, the larvae become capable to reside in water with DO concentrations below $3.5 \mathrm{mg} \cdot \mathrm{L}^{-1}$ and thus can utilize a niche in the water column where they are rather safe from fish predation.

In dimictic lakes, DO concentrations below $3.5 \mathrm{mg} \cdot \mathrm{L}^{-1}$ develop during the spring season, and typically, DO becomes available when instar III larvae develop. Instar IV larvae, however, that produce the eggs for the new generation of $C$. flavicans after the winter season, have to persist through fall mixing, over the winter month, and through spring mixing. During these time periods, DO concentrations are typically above $3.5 \mathrm{mg} \cdot \mathrm{L}^{-1}$ in the entire water column. Survival of instar IV larvae, therefore, is substantially supported by their tolerance of anoxic conditions. This tolerance allows instar IV larvae to hide during daytime not only in anoxic waters but also in anoxic sediments. The latter is particularly important during the winter - early spring period when DO concentrations are typically above $3.5 \mathrm{mg} \cdot \mathrm{L}^{-1}$ in the entire water column.

The observed DVM patterns may be additionally influenced by differences in the diet preferences of the different Chaoborus instars. Younger instars are known to prey mainly on small rotifers and flagellated phytoplankton, whereas the larger instars III and IV prey on larger rotifers and crustaceans (Moore 1988). The smaller prey organisms are more abundant in the upper water column and typically do not perform DVM, whereas the larger crustaceans typically show regular DVM (Gliwicz 1986; Lampert 1989).

Prey organisms typically do not stay in water with very low DO concentrations. Larvae of instars III and IV therefore migrate upwards at night for feeding, which explains the low ABS at depths with anoxic waters during nighttime (Figs. $1 a, 2 a, 3 c$ ). The lack of prey in anoxic waters may also be one of the reasons why larvae of instars I and II have not developed a migration pattern with a large amplitude into waters with low DO concentrations. During the time period in the season when instar I larvae occur for the first time in the water column, oxygen levels are typically high, and niches with low oxygen protecting from fish predation may not be reliably available. It is therefore advantageous for the Chaoborus population that small instar larvae develop rapidly into larger instars that can migrate into deep waters with low DO concentrations or into anoxic sediments. Rapid growth of body size and development into larger instars can be achieved most effectively by intensive feeding during day and night and requires residence in oxygen-rich water in which prey is abundant. By the time instar II larvae develop into instar III larvae, low DO concentrations have developed in deeper waters, providing safe niches within the water column for the instar III larvae.

The vertical distribution of DO and the seasonal development of DO in the water column differed between the 2 years of observation in Lake Illmensee, which affected the migration patterns of the instars of $C$. flavicans. The main factor that caused the change in the vertical distribution of DO in Lake Illmensee was the DCM, which was due to a large abundance of the cyanobacterium P. rubescens in 2014 that formed a dense layer at about 8-9 m water depth in Lake Illmensee (Fig. 7b). The metabolism of P. rubescens resulted in a maximum in the vertical DO distribution at the depth of the $P$. rubescens layer between 8 and $9 \mathrm{~m}$ water depth and a rapid decline of the DO concentration below this layer. As a consequence, the 0.5 and $3.5 \mathrm{mg} \cdot \mathrm{L}^{-1} \mathrm{DO}$ isolines approached each other very closely, and the residence depth of larvae of instars II and III overlapped during daytime (Fig. 6). In 2014, the $3.5 \mathrm{mg} \cdot \mathrm{L}^{-1}$ DO isoline was at deeper water depth than in 2013. Instar II larvae were therefore able to migrate with a larger vertical amplitude in 2014 than in 2013. After 2 weeks of development time, instar II larvae migrated to $\sim 9 \mathrm{~m}$ depth in 2014 but only to $\sim 7-8 \mathrm{~m}$ in 2013. Note, that in 2014 the larvae of instars II and III resided during daytime within or just below the DCM. As P. rubescens produces microcystins that are toxic for fish (Fischer et al. 2000; Malbrouck and Kestemont 2006; Ibelings and Havens 2008), the P. rubescens layer may have provided additional protection for the Chaoborus larvae from fish predation.

The DCM in 2014 in Lake Illmensee was not only associated with a strong peak in DO but also with a larger vertical extent of the anoxic layer. Most likely, respiration by P. rubescens below the zone of production has increased oxygen consumption in the deep water. Instar IV larvae utilized the large vertical extent of the anoxic deep water and remained in the anoxic water during daytime. They did not migrate into the sediments as in Lake Illmensee in 2013 or in Lake Mindelsee in 2015.

Summarizing, the combination of long-term ADCP data with measurements of the temporal development of the vertical distribution of DO enabled us not only to compare the DVM patterns of the different instars of $C$. flavicans in 3 different years and in two different lakes but also to relate the temporal changes in DVM to the seasonal development of DO in the water column. Nevertheless, traditional zooplankton net samplings are needed to support the interpretation of the ADCP with respect to the identification of the different instars and thus will remain a fundamental part of the analysis of zooplankton dynamics.

Larvae of instars II to IV of $C$. flavicans show regular DVM. The amplitude and timing of upward and downward migration and the residence depth during daytime differs among instars. Not only the vertical distribution of light intensity but also the vertical distribution of DO affects the migration pattern. The physiology of the different instars matches with their migration behavior. With ontogenetic development, the tolerance to low DO concentrations and the sensitivity to light intensity of $C$. flavicans larvae increases, making larger amplitude DVM possible and allowing larger instars to utilize niches in the water column that are protected from fish predation. The ontogenetic development supporting migration capabilities matches with the seasonal development of abiotic conditions and especially with the development of anoxic deep waters. Interannual variations in migrational patterns can 
be caused by interannual changes in the abundance and vertical distribution of phytoplankton altering the abiotic environmental conditions sufficiently to change the migration behavior of carnivorous zooplankton.

\section{Acknowledgements}

We thank J. Halder and B. Rosenberg for their technical support in the field and P. Mahler for phytoplankton analysis. P. Hingsamer, A. Seifried, P. Mahler, A. Keller, M. Hornung, L. Hoxha, P. Gerster, B. Stehle, G.F. Bodnar, and C. Roxana helped during the different field campaigns and with the preparation of zooplankton and phytoplankton samples. We also thank T. Irwin for the determination of the Chaoborus species. The research was supported by several local authorities: The Regional Council Tübingen, Pro Regio Upper Swabia, the District offices Sigmaringen and Konstanz, the Municipality Illmensee, and the German Society for Nature Conservation. The Department of Biology at the University of Konstanz financially supported the field work. The position of M. Weisser was financed by the University of Konstanz (grant: AFF 38/03).

\section{References}

Barth, L.E., Sprules, W.G., Wells, M., and Coman, M. 2014. Seasonal changes in the diel vertical migration of Chaoborus punctipennis larval instars. Can. J. Fish. Aquat. Sci. 71(5): 665-674. doi:10.1139/cjfas-2013-0440.

Berg, K. 1937. Contributions to the biology of Corethra Meigen (Chaoborus Lichtenstein). Kgl. Danske Videnskab. Selskab. Biol. Medd. 13: 1-101.

Chimney, M.J., Herring, M.K., and Bowers, J.A. 2007. Instar determination, length-mass and length-length relationships for the larvae of Chaoborus punctipennis Say from a southeastern (USA) cooling reservoir. Fund. Appl. Limnol. 168(2): 163-168. doi:10.1127/1863-9135/2007/0168-0163.

Cuypers, Y., Vinçon-Leite, B., Groleau, A., Tassin, B., and Humbert, J.-F. 2011. Impact of internal waves on the spatial distribution of Planktothrix rubescens (cyanobacteria) in an alpine lake. ISME J. 5: 580-589. doi:10.1038/ismej.2010. 154. PMID:21085197.

Diomande, D., Tie-Bi, T., Franquet, E., Maasri, A., Quattara, A., and Gourene, G. 2010. Temporal dynamics of Chaoborus larvae (Diptera: Chaoboridae) in the tropical ecosystem (lake Ayamé I; Cote d'Ivoire). Sci. Nat. 7(1): 51-58. doi:10. 4314/scinat.v7i1.59927.

Fedorenko, A.Y., and Swift, M.C. 1972. Comparative biology of Chaoborus americanus and Chaoborus trivittatus in Eunice Lake, British Columbia. Limnol. Oceanogr. 17(5): 721-730. doi:10.4319/10.1972.17.5.0721.

Fischer, W.J., Hitzfeld, B.C., Tencalla, F., Eriksson, J.E., Mikhailov, A., and Dietrich, D.R. 2000. Microcystin-LR toxicodynamics, induced pathology, and immunohistochemical localization in livers of blue-green algae exposed rainbow trout (Oncorhynchus mykiss). Toxicol. Sci. 54(2): 365-373. doi:10.1093/ toxsci/54.2.365. PMID:10774818.

Garneau, M.-È., Posch, T., Hitz, G., Pomerleau, F., Pradalier, C., Siegwart, R.Y., and Pernthaler, J. 2013. Short-term displacement of Planktothrix rubescens (cyanobacteria) in a pre-alpine lake observed using an autonomous sampling platform. Limnol. Oceanogr. 58: 1892-1906. doi:10.4319/lo.2013.58.5.1892.

Gliwicz, Z.M. 1986. Predation and the evolution of vertical migration in zooplankton. Nature, 320: 746-748. doi:10.1038/320746a0.

Gliwicz, Z.M., Biernacka, A., Pijanowska, J., and Korsak, R. 2000. Ontogenetic shifts in the migratory behavior of Chaoborus flavicans Meigen: field and experimental evidence. Arch. Hydrobiol. 149: 193-212. doi:10.1127/archiv-hydrobiol/ $149 / 2000 / 193$

Haney, J.F., Craggy, A., Kimball, K., and Weeks, F. 1990. Light control of evening vertical migrations by Chaoborus punctipennis larvae. Limnol. Oceanogr. 35(5): 1068-1078. doi:10.4319/lo.1990.35.5.1068.

Huber, A.M.R., Peeters, F., and Lorke, A. 2011. Active and passive vertical motion of zooplankton in a lake. Limnol. Oceanogr. 56(2): 695-706. doi:10.4319/lo. 2011.56.2.0695.

Ibelings, B.W., and Havens, K.E. 2008. Cyanobacterial toxins: a qualitative metaanalysis of concentrations, dosage and effects in freshwater, estuarine and marine biota. Adv. Exp. Med. Biol. 619: 675-732. doi:10.1007/978-0-387-758657 32. PMID:18461789.

Jäger, I.S., and Walz, N. 2003. Unusual allometry between respiration rate and body size in Chaoborus species. J. Plankton Res. 25(3): 255-260. doi:10.1093/ plankt/25.3.255.

La Row, E.J., and Marzlof, G.R. 1970. Behavioral differences between 3rd and 4th instars of Chaoborus punctipennis Say. Am. Midl. Nat. 84(2): 428-436. doi:10. $2307 / 2423858$.

Lagergren, R., Leberfinger, K., and Stenson, J.A.E. 2008. Seasonal and ontogenetic variation in diel vertical migration of Chaoborus flavicans and its effect on depth-selection behavior of other zooplankton. Limnol. Oceanogr. 53(3): 1083-1092. doi:10.4319/1o.2008.53.3.1083.

Lair, N. 1990. Effects of invertebrate predation on the seasonal succession of a zooplankton community: a two year study in Lake Aydat, France. Hydrobiologia, 198: 1-12. doi:10.1007/BF00048618.

Lampert, W. 1989. The adaptive significance of diel vertical migration of zooplankton. Funct. Ecol. 3: 21-27. doi:10.2307/2389671.

Lewis, W.M. 1975. Distribution and feeding habits of a tropical Chaoborus population. Verh. Int. Verein. Theor. Angew. Limnol. 19: 3106-3119.

Lorke, A., McGinnis, D.F., Spaake, P., and Wuest, A. 2004. Acoustic observations of zooplankton in lakes using a Doppler current profiler. Freshw. Biol. 49: 1280-1292. doi:10.1111/j.1365-2427.2004.01267.x.

Luecke, C. 1986. A change in the pattern of vertical migration of Chaoborus flavicans after the introduction of trout. J. Plankton Res. 8(4): 649-657. doi:10. 1093/plankt/8.4.649.

Malbrouck, C., and Kestemont, P. 2006. Effects of microcystins on fish. Environ. Toxicol. Chem. 25(1): 72-86. doi:10.1897/05-029R.1. PMID:16494227.

Malinen, T., Horppila, J., and Liljendahl-Nurminen, A. 2001. Langmuir circulations disturb the low-oxygen refuge of phantom midge larvae. Limnol. Oceanogr. 46: 689-692. doi:10.4319/lo.2001.46.3.0689.

Martin-Creuzburg, D., Kowarik, C., and Straile, D. 2017. Cross-ecosystem fluxes: export of polyunsaturated fatty acids from aquatic to terrestrial ecosystems via emerging insects. Sci. Total Environ. 577: 174-182. doi:10.1016/j.scitotenv. 2016.10.156. PMID:27810302.

Moore, M.V. 1942. Field studies on the oxygen requirements of certain freshwater fishes. Ecology, 23(3): 319-329. doi:10.2307/1930671.

Moore, M.V. 1988. Differential use of food resources by the instars of Chaoborus punctipennis. Freshw. Biol. 19(2): 249-268. doi:10.1111/j.1365-2427.1988.tb00346.x.

Ohman, M., Frost, B.W., and Cohen, E.B. 1983. Reverse diel vertical migration: an escape from invertebrate predators. Science, 220(4604): 1404-1407. doi:10. 1126/science.220.4604.1404. PMID:17730658.

Parma, S. 1971. The morphology of Chaoborus flavicans (Meigen, 1818) (Diptera, Chaoboridae). Beaufortia, 18: 173-182.

Smukalla, R., and Meyer, E. 1988. Insect emergence from a shallow southern West German lake, with special reference to the parasitic host-associated water mite larvae. Hydrobiologia, 169: 149-166. doi:10.1007/BF00007307.

Stratton, M.A., and Kesler, D.H. 2007. The role of light and oxygen in Chaoborus punctipennis (Insecta: Diptera) diel vertical migration. J. Freshw. Ecol. 22(1): 101-106. doi:10.1080/02705060.2007.9664150.

Swift, M.C., and Forward, R.B. 1980. Photoresponses of Chaoborus larvae. J. Insect Physiol. 26: 365-371. doi:10.1016/0022-1910(80)90006-2.

Swift, M.C., and Forward, R.B. 1982. Photoresponses of second-instar Chaoborus larvae. J. Insect Physiol. 28: 183-187. doi:10.1016/0022-1910(82)90127-5.

Teraguchi, M., and Northcote, T.G. 1966. Vertical distribution and migration of Chaoborus flavicans larvae in Corbett Lake, British Columbia. Limnol. Oceanogr. 11(2): 164-176. doi:10.4319/10.1966.11.2.0164.

Von Ende, C. 1982. Phenology of four Chaoborus species. Environ. Entomol. 11(1): 9-15. doi:10.1093/ee/11.1.9.

Voss, S., and Mumm, H. 1999. Where to stay by night and day: size-specific and seasonal differences in horizontal and vertical distribution of Chaoborus flavicans larvae. Freshw. Biol. 42: 201-213. doi:10.1046/j.1365-2427.1999.444444.x. 